University of Montana

ScholarWorks at University of Montana

$12-2002$

\title{
Plasticity and Genetic Diversity May Allow Saltcedar to Invade Cold Climates in North America
}

Jason P. Sexton

J. K. McKay

Anna Sala

University of Montana - Missoula, sala@mso.umt.edu

Follow this and additional works at: https://scholarworks.umt.edu/biosci_pubs

Part of the Biology Commons

Let us know how access to this document benefits you.

\section{Recommended Citation}

Sexton, Jason P.; McKay, J. K.; and Sala, Anna, "Plasticity and Genetic Diversity May Allow Saltcedar to Invade Cold Climates in North America" (2002). Biological Sciences Faculty Publications. 13.

https://scholarworks.umt.edu/biosci_pubs/13

This Article is brought to you for free and open access by the Biological Sciences at ScholarWorks at University of Montana. It has been accepted for inclusion in Biological Sciences Faculty Publications by an authorized administrator of ScholarWorks at University of Montana. For more information, please contact

scholarworks@mso.umt.edu. 


\title{
PLASTICITY AND GENETIC DIVERSITY MAY ALLOW SALTCEDAR TO INVADE COLD CLIMATES IN NORTH AMERICA
}

\author{
Jason P. Sexton, ${ }^{1}$ John K. McKay, and Anna Sala \\ Division of Biological Sciences, University of Montana, Missoula, Montana 59812 USA
}

\begin{abstract}
Two major mechanisms have been proposed to explain the ability of introduced populations to colonize over large habitat gradients, despite significant population bottlenecks during introduction: (1) Broad environmental tolerance-successful invaders possess life history traits that confer superior colonizing ability and/or phenotypic plasticity, allowing acclimation to a wide range of habitats. (2) Local adaptation-successful invaders rapidly adapt to local selective pressures. However, even with bottlenecks, many introduced species exhibit surprisingly high levels of genetic variation and thus the potential for evolutionary increases in invasive traits and plasticity. Here we assess the invasive potential of Tamarix ramosissima, by examining the degree of genetic differentiation within and among populations from the latitudinal extremes of its introduced range. Using growth chamber experiments we examined ecologically important variation in seedlings, both in trait means and their reaction norms across temperature environments. Although we found no genetic variation for gas exchange traits, within or among populations, we did find significant genetic variation for growth traits, both in the trait means and in the degree of plasticity in these traits. Northern ecotypes invested more in roots relative to southern ecotypes but only under low temperatures. Both ecotypes increased shoot investment in warm temperatures. Increased root investment in cold temperatures by northern ecotypes may increase their first winter survival. Genetic differences in seedling root investment may contribute to the ability of this species to successfully tolerate and invade a broader latitudinal range. Our data support a model in which both plasticity and adaptive evolution can contribute to the invasive potential of introduced species.
\end{abstract}

Key words: ecological genetics; ecotypes; invasive potential; invasiveness; local adaptation; plasticity; root mass ratio; saltcedar; Tamarix ramosissima.

\section{INTRODUCTION}

What is the eventual fate of introduced species? Which ones will survive and flourish? From an evolutionary perspective, species introductions are essentially human caused migration events, where individuals are translocated to a novel environment. Once introduced, some species survive and establish self-sustaining populations in the novel habitat. A subset of these species may not only survive in their new habitat, but become invasive, dominating the new community and even causing the extinction of natives through rampant growth and/or indirect effects. In an effort to predict the invasive potential of exotic species attempts have been made to identify traits associated with invasiveness in plant species, but little consensus has emerged (Goodwin et al. 1999, Mack et al. 2000).

In addition to intrinsic site susceptibility to invasion, the ability of an introduced species to successfully tolerate and invade broad geographic areas has been re-

Manuscript received 31 August 2001; revised 22 February 2002; accepted 5 March 2002; final version received 18 March 2002.

${ }^{1}$ Present address: Sweeney Granite Mountains Desert Research Center, University of California, Riverside, P.O. Box 101, Kelso, California 92351 USA.

E-mail: gmdrc@inreach.com lated to two main mechanisms: broad environmental tolerance and local adaptation (Schlichting 1986, Williams and Black 1993). We use a conceptual model of invasion (Fig. 1), which incorporates both plasticity and adaptation of introduced species, and may help to explain the often large time lag between species introduction and invasion (Baker 1986, Ellstrand and Schierenbeck 2000). Plasticity may initially allow introduced species the environmental tolerance to become naturalized across a range of environments (Baker 1974). Once naturalized, recombination of genetic variation among introduced individuals can provide a range of heritable phenotypes to respond to local selection pressures and produce offspring with higher fitness (Ellstrand and Schierenbeck 2000). We argue that invasive potential can sometimes be viewed as a suite of evolutionarily labile traits, and thus attempts to predict which species are likely to become invasive based on current trait means or characters alone may be misleading (Rejmánek and Richardson 1996, Williamson and Fitter 1996a, Goodwin et al. 1999, Mack et al. 2000). We assert that non-native species (as with native species) that appear to be less noxious cannot be assumed to remain so because their invasive potential may increase during the apparently stable naturalization phase via microevolutionary processes.

It is clear that, given strong selection and ample ge- 
FIG. 1. Hypothetical time course for the frequency of an invasive species. Initially, phenotypic plasticity may increase the range of habitats into which the introduced species can become naturalized. Once the species is naturalized, local selection may favor a subset of the introduced genotypes. Eventually a combination of founder effects, gene flow, mutation, and recombination may create individuals in the newly naturalized population with a phenotype closer to the optimum for the novel habitat. In some cases, adaptive evolution may lead to an increase in plasticity for some traits, and to an increase in "invasiveness" in the introduced population. For species that have been subject to multiple introductions, the potential for invasiveness (or local adaptation) to evolve rapidly may be great.

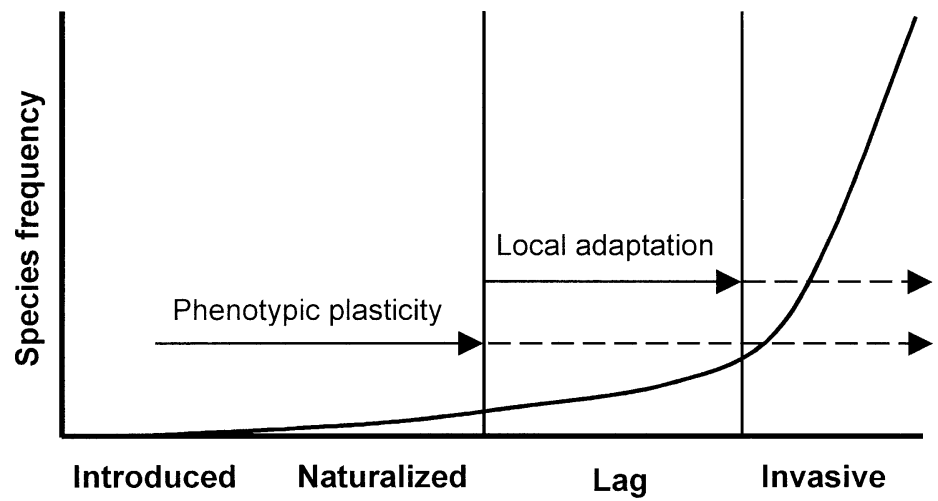

resented by: different norms of reaction (Falconer 1990) evidenced by significant genotype by environment interaction (Fry 1992), or a genetic correlation of a character across environments that is less than one (Stearns 1989, Falconer 1990). As with genetic differences in trait means, the ability of genotypes to be plastic cannot be assumed to be adaptive. However, the high degree of plasticity in ecophysiological traits is hypothesized to be an adaptation for dealing with environmental heterogeneity (Bell and Lechowicz 1994).

The relative contribution of phenotypic plasticity and adaptation to invasiveness has received little attention. Here we use ecological genetics to examine invasive potential in the exotic invasive shrub saltcedar (Tamarix ramosissima Ledeb.). Saltcedar is native to Eurasia where it occupies lakeshore, marsh, river, and steppe habitats (Baum 1978). Because it is so aggressive in riparian ecosystems of the southwestern United States, research has focused on identifying traits of saltcedar that aid in its invasive and competitive ability (Busch and Smith 1995, Sala et al. 1996, Cleverly et al. 1997, Smith et al. 1998). In its native range, saltcedar maintains an enormous distribution across the breadth of Eurasia, from Turkey to North Korea, from Iran to Ukraine (see Baum 1978). Consistent with its broad latitudinal native distribution, saltcedar occupies the latitudinal breadth of the western contiguous U.S. (see map in Brock 1994), and it has spread throughout the northern United States since the 1960s. However, in colder areas it appears to be less invasive than in the Southwest (Lesica and Miles 2001). It is likely that multiple introductions of saltcedar in North America (Robinson 1965) from different regions of its large native range have resulted in considerable genetic variation available for adaptation in these non-native populations.

If non-neutral genetic variation exists across habitats, it can contribute to local adaptation in the new range of distribution of this species. Temperature has strong effects on plant growth and survival, limiting ecotype and species distributions (Berry and Bjorkman

1980, Berry and Raison 1981, Woodward 1986). There-
We believe this is very important for the ecology of invasion. Genetic differences in plasticity can be rep- 


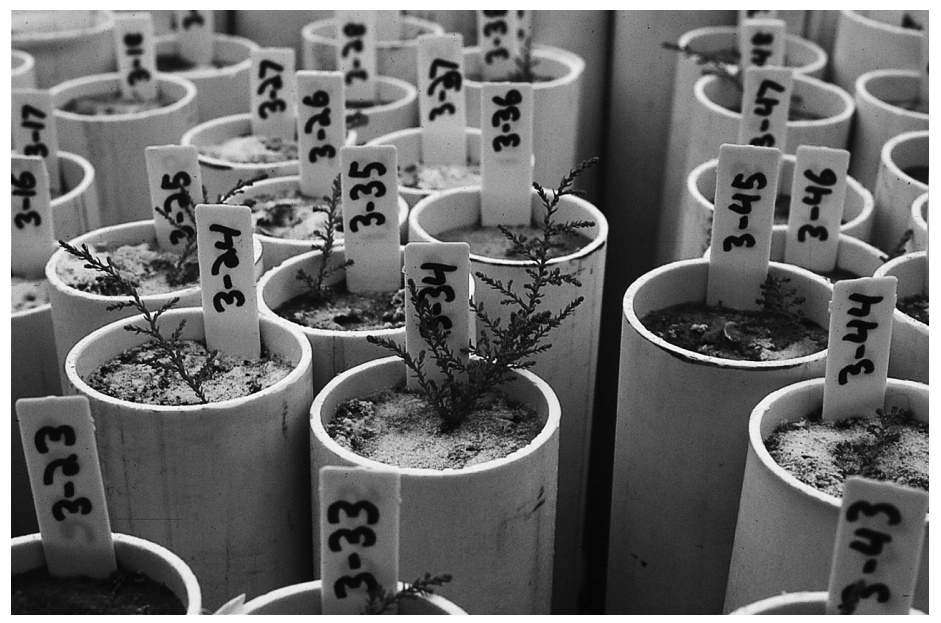

Plate 1. Saltcedar seedlings emerging within an environmental chamber approximating summer growing conditions in southern Arizona. Photograph by Jason P. Sexton.

fore, a latitudinal gradient should represent a selective gradient for saltcedar due to temperature and growing season differences. For instance, seedlings at colder, northern latitudes with shorter growing seasons are less developed when they overwinter, leading to high seedling mortality. We measured genetic variation in functional trait means and reaction norms of saltcedar across two temperature treatments. To determine the potential of saltcedar to use plasticity and local adaptation to increase its invasiveness in the wide range of habitats to which it has become naturalized we asked: (a) Does genetic variation exist for functional traits within and among non-native populations of saltcedar? (b) Does a genotype by environment interaction exist for these responses? (c) If so, do these responses fit a model of functional, invasive ecotypes for respective populations?

\section{Materials and Methods \\ Climates and sampling}

We sampled populations at the extremes of the latitudinal range of saltcedar in the western United States. Seeds were collected in June and July 1998 in each of three riparian populations in southern Arizona and eastern Montana. To account for possible population structuring, populations within these regions were delineated as stands of saltcedar at a minimum distance of $10 \mathrm{~km}$ from each other. Seeds were collected randomly from five plants at each population for a total of 15 families from each region. A family consists of a seed set derived from a single plant in the field. Seed source populations from Arizona and Montana will hereafter be referred to as Southern and Northern, respectively.

Southern populations were sampled along the Gila River within lower Sonoran bajada habitat, a drainage historically dominated by Populus fremontii, Salix goodingii, and Prosopis velutina (Haase 1972). This low elevational gradient portion of the Gila River, now dominated by near-monospecific stands of saltcedar, has been subjected to myriad human disturbances including clearing for agriculture, water diversion, and flood control (Minckley and Brown 1994). Seed production at these sites can occur over half the year, from May to October (Warren and Turner 1975). Southern seeds were collected at three locations: $33^{\circ} 20.5^{\prime} \mathrm{N}$, $112^{\circ} 37.5^{\prime} \mathrm{W} ; 33^{\circ} 22.7^{\prime} \mathrm{N}, 112^{\circ} 19.5^{\prime} \mathrm{W} ; 33^{\circ} 15.2^{\prime} \mathrm{N}$, $112^{\circ} 09.7^{\prime}$ W. Nearby Buckeye, Arizona, experiences an average of 344 frost-free days, with June-August having Min./Max. air temperatures of $22.4^{\circ} / 41.9^{\circ} \mathrm{C}$, and an overall mean of $32.1^{\circ} \mathrm{C}$ for that period (Garwood 1996).

Northern populations were sampled within the Great Plains along low elevational gradient stretches of the Yellowstone and Bighorn rivers at similar elevations within a distance of $50 \mathrm{~km}$. These sites are dominated by Populus deltoides, Salix exigua, Shepherdia argentea, and Symphoricarpos occidentalis (Hansen et al. 1995). At these sites, saltcedar occurs mostly in discrete patches or stands within $100 \mathrm{~m}$ of the main channel and on river channel islands. Saltcedar commonly occurs at these sites where disturbances of grazing, development and flooding are apparent. Seed production at these sites occurs from late June through September. Northern seeds were collected at three locations: $46^{\circ} 08.4^{\prime} \mathrm{N}, 107^{\circ} 27.8^{\prime} \mathrm{W} ; 45^{\circ} 50.6^{\prime} \mathrm{N}, 107^{\circ} 35.2^{\prime}$ W; 46 $15.4^{\prime} \mathrm{N}, 107^{\circ} 20.3^{\prime}$ W. Nearby Hysham, Montana, experiences an average of 191 frost-free days, with June-August having Min./Max. air temperatures of $11.6^{\circ} / 29.8^{\circ} \mathrm{C}$, and an overall mean of $20.7^{\circ} \mathrm{C}$ for that period (Garwood 1996).

\section{Growth chambers}

Saltcedar plants were grown within two controlled environmental chambers (EGC Plant Growth Chambers, Chagrin Falls, Ohio) in 14-h days, 10-h nights under a mixture of incandescent and fluorescent lights (400-550 $\mu \mathrm{mol}$ photons $\cdot \mathrm{m}^{-2} \cdot \mathrm{s}^{-1}$ ) (see Plate 1$)$. Seeds were germinated in water for $2 \mathrm{~d}$ and then transferred 
to mesh-bottom PVC plastic pipes $(5 \mathrm{~cm}$ diameter $\times$ $1 \mathrm{~m}$ height, to accommodate the future tap root) filled with $2.0 \mathrm{~L}$ of moderate coarsity silica sand $(0.58-\mathrm{mm}$ grains in the upper $5 \mathrm{~cm}$, and 0.20 - $\mathrm{mm}$ grains below). Germination conditions were $12^{\circ} / 20^{\circ}$ and $15^{\circ} / 20^{\circ} \mathrm{C}$ (night/day) in the low- and high-temperature chambers, respectively. Germinated seeds were transplanted such that each chamber contained seeds from the two regions $\times$ three populations per region $\times$ five families per population $\times$ ten replicates per family for a total of 300 plants (600 plants for the experiment). Plants were arranged into five experimental blocks per chamber, each block containing two randomly positioned representatives of each family to account for within treatment heterogeneity (Potvin and Tardif 1988). Pipes were capped with transparent plastic cups for two days after planting to avoid desiccation of seedling roots at the soil surface. Growth conditions in the two chambers were diverged gradually over two weeks to represent Southern $\left(20^{\circ} / 37^{\circ} \mathrm{C}\right)$ and Northern $\left(11^{\circ} / 25^{\circ} \mathrm{C}\right)$ field conditions. Emerging seedlings were thinned to one per PVC pipe. Soil moisture was held near saturation during seedling onset ( $2 \mathrm{wk}$ ) and sand was kept moist during the remainder of the growth period by partially submerging the pipes to half their height in plastic tanks. Plants were watered daily and fertilized every two weeks with Peters 20-20-20 NPK fertilizer (W. R. Grace, Fogelsville, Pennsylvania) throughout the experimental period. Temperature and relative humidity at plant canopy height were continuously monitored throughout the experiment with a CR10X data logger (Campbell Scientific, Logan, Utah). Daytime vapor pressure deficits of the air in the chambers were 1.3 and $3.4 \mathrm{kPa}$ in the low- and high-temperature chambers, respectively.

\section{Gas exchange}

After $99 \mathrm{~d}$ of growth we measured net photosynthetic rate $\left(A_{\mathrm{n}}\right)$ and stomatal conductance $(g)$ from one block (60 plants) in each chamber using a LI-COR 6200 portable photosynthesis system (LI-COR, Lincoln, Nebraska). Mean air temperatures during gas exchange measurements were $23^{\circ}$ and $35^{\circ} \mathrm{C}$ in the low- and hightemperature chambers, respectively. Transpiration rate $(E)$ was calculated from $g$ and independent measurements of air temperature and relative humidity, assuming similar air and leaf temperatures. Instantaneous water-use efficiency ( $W_{U E} E_{\text {inst }}$ ) was calculated from measurements of $A_{\mathrm{n}}$ and $E$. Gas exchange parameters were expressed on a leaf dry mass basis.

\section{Growth and biomass allocation}

After $86 \mathrm{~d}$ plants were harvested one block at a time over a 21-d period. Roots and shoots were washed, separated, then oven dried for a minimum of $48 \mathrm{~h}$ at $60^{\circ} \mathrm{C}$. Dried roots and shoots were weighed separately and total plant masses were calculated for each individual. Shoot and root lengths were measured at time
TABLE 1. Summary of analysis of variance for temperature responses of Tamarix ramosissima within growth chambers for gas exchange traits: net photosynthesis on a dry mass basis $\left(A_{\mathrm{n}}\right)$, stomatal conductance $(g)$, transpiration $(E)$, and instantaneous water-use efficiency ( $\left.\mathrm{WUE}_{\text {inst }}\right)$.

\begin{tabular}{lcccc}
\hline \hline $\begin{array}{c}\text { Dependent } \\
\text { variable }\end{array}$ & Type III ss & df & $F$ & $\begin{array}{c}\text { Signifi- } \\
\text { cance }\end{array}$ \\
\hline Temperature & & & & \\
$A_{\mathrm{n}}$ & 214441.415 & 1 & 7.474 & 0.008 \\
$g$ & 7.811 & 1 & 30.594 & 0.000 \\
$E$ & 13.658 & 1 & 78.430 & 0.000 \\
$\quad$ WUE & 5.268 & 1 & 33.998 & 0.000 \\
Reginst & & & & \\
$A_{\mathrm{n}}$ & 29073.926 & 1 & 1.194 & 0.281 \\
$g$ & 0.204 & 1 & 1.623 & 0.208 \\
$E$ & 0.361 & 1 & 3.781 & 0.058 \\
WUE $_{\text {inst }}$ & 0.06878 & 1 & 0.665 & 0.419 \\
Family & & & & \\
$A_{\mathrm{n}}$ & 685748.867 & 29 & 0.824 & 0.715 \\
$g$ & 3.048 & 29 & 0.412 & 0.995 \\
$E$ & 2.407 & 29 & 0.477 & 0.986 \\
WUE $_{\text {inst }}$ & 2.762 & 29 & 0.615 & 0.928 \\
Region $\times$ Temperature & & & \\
$A_{\mathrm{n}}$ & 20744.449 & 1 & 0.723 & 0.398 \\
$g$ & 0.03798 & 1 & 0.149 & 0.701 \\
$E$ & 0.007872 & 1 & 0.045 & 0.832 \\
WUE $_{\text {inst }}$ & 0.02869 & 1 & 0.185 & 0.668 \\
\hline
\end{tabular}

Notes: Results are from four separate ANOVAs (one for each trait). In this mixed model randomized block design, family is a random factor nested within region. Data for $g$, $E$, and $\mathrm{WUE}_{\text {inst }}$ were $\log$ transformed before analysis.

of harvest. In addition we calculated root mass ratio (RMR), as the root mass divided by total mass.

\section{Statistics}

Data were analyzed using analysis of variance (procedure GLM, in the SAS statistical package, version 6.12 [Freund et al. 1991]). Because we were primarily interested in among region differences, the effect of region was considered a fixed factor and family was considered a random factor nested within region. Population, nested within region, was initially included in the analysis but was excluded because it did not improve model fit. Because whole blocks were harvested at once, the effect of block is confounded by the effect of harvest date and thus we used harvest date as a covariate. Due to non-normality (skewness), data were natural $\log$ and cube root transformed to meet the assumptions of parametric analysis.

\section{RESUlts}

\section{Gas exchange}

We did not find evidence for genetic variation at local (i.e., a significant effect of family or population) or regional spatial scales in gas exchange traits $(P>0.05$ for family and region effects; Table 1). A lack of any significant effect of family or population may be partly due to the reduced sample size for these traits. Due to a lack of genetic effect we pooled all data to examine 
TABLE 2. Summary of analysis of variance for temperature responses of Tamarix ramosissima within growth chambers for growth traits.

\begin{tabular}{lcccl}
\hline \hline $\begin{array}{c}\text { Dependent } \\
\text { variable }\end{array}$ & Type III ss & df & $F$ & \multicolumn{1}{c}{$P$} \\
\hline Harvest time (covariate) & & & \\
RMR & 1.33 & 1 & 32.62 & 0.00000005 \\
Total mass & 17.366 & 1 & 41.39 & 0.0000000005 \\
Root mass & 28.309 & 1 & 50.84 & 0.0000000005 \\
Shoot mass & 13.014 & 1 & 32.84 & 0.00000005 \\
Shoot length & 3.819 & 1 & 30.55 & 0.00000005 \\
Temperature & & & & \\
RMR & 9.337 & 1 & 228.93 & 0.0000000005 \\
Total mass & 53.139 & 1 & 126.67 & 0.0000000005 \\
Root mass & 17.927 & 1 & 32.20 & 0.00000005 \\
Shoot mass & 75.496 & 1 & 190.52 & 0.0000000005 \\
Shoot length & 30.912 & 1 & 296.13 & 0.0000000005 \\
Region & & & & \\
RMR & 0.321 & 1 & 2.24 & 0.15 \\
Total mass & 0.170 & 1 & 0.18 & 0.7 \\
Root mass & 0.957 & 1 & 0.68 & 0.5 \\
Shoot mass & $4.484 \mathrm{E}-03$ & 1 & 0.01 & 0.95 \\
Shoot length & 0.929 & 1 & 4.07 & 0.06 \\
Family & & & & \\
RMR & 4.023 & 28 & 3.52 & 0.000000005 \\
Total mass & 25.999 & 28 & 2.218 & 0.0005 \\
Root mass & 39.583 & 28 & 2.54 & 0.0005 \\
Shoot mass & 22.702 & 28 & 2.05 & 0.005 \\
Shoot length & 6.426 & 28 & 2.20 & 0.0005 \\
Region $\times$ temperature & & & \\
RMR & 0.688 & 1 & 16.86 & 0.00005 \\
Total mass & 0.378 & 1 & 0.90 & 0.35 \\
Root mass & $4.610 \mathrm{E}-02$ & 1 & 0.08 & 0.78 \\
Shoot mass & 1.094 & 1 & 2.76 & 0.1 \\
Shoot length & $7.292 \mathrm{E}-02$ & 1 & 0.70 & 0.5 \\
\hline & & & & \\
\hline
\end{tabular}

Notes: The interaction between region and temperature for the trait root mass ratio (RMR) was significant. Data were analyzed using a mixed model (randomized block design), where family was considered a random factor nested within region. Harvest time was used as a covariate within this model. Data were transformed prior to analysis to improve normality: shoot mass, root mass, total mass, and RMR were natural $\log$ transformed; shoot length was cube root transformed. Results are from five separate ANOVAs (one for each trait).

phenotypic plasticity in these traits as a function of temperature. All gas exchange variables (means \pm 1 SE) differed significantly between the high- and lowtemperature environments (Table 1). Higher temperature increased $A_{\mathrm{n}}$ by $21.5 \%(P=0.008), E$ by $122.6 \%$ $(P<0.001)$, and $g$ by $189 \%(P<0.001)$, and decreased WUE $_{\text {inst }}$ by $33.3 \%(P<0.001)$.

\section{Growth and biomass allocation}

Like the gas exchange parameters, all growth traits changed significantly with temperature. Unlike gas exchange, we found evidence for genetic variation in growth traits. The effect of family nested within region was significant for all traits (Table 2), indicating that genetic variation exists within regions. The effect of region was marginally significant only for shoot length ( $P=0.06)$ with longer shoots for Southern seedlings in both temperature environments (Fig. 2). The interaction term, region $\times$ temperature, was only significant for RMR. Northern seedlings had significantly higher RMR than Southern seedlings at low temperature, but not at high temperature, reflected as a significant genotype $\times$ environment interaction (Table 2, Fig. 2). In the cold chamber the mean root investment of Northern families $(\mathrm{RMR}=0.370)$ was greater than for that of Southern families $(\mathrm{RMR}=0.334)$. In the hot chamber the means of Northern families $(\mathrm{RMR}=0.265)$ was almost identical to that of Southern families ( RMR $=$ 0.270). An ANOVA using family means showed a significant regional effect in the cold chamber $(F=10.1$, $P<0.005)$, but not in the hot treatment $(F=0.0, P$ $=0.539)$. In order to examine the genetic correlation between RMR in a hot environment and RMR in a cold environment within both regions, we calculated Pearson's correlation among least-squares family means (controlling for harvest date, Fig. 3) and computed 95\% confidence intervals (CI) for the correlation between these two traits using a $z$-transformation (Sokal and Rolf 1995). For both regions the correlation of family means for RMR cold and RMR hot was significantly different from both zero and one. Southern and Northern families had correlation coefficients of $0.72(95 \%$ $\mathrm{CI}=0.33,0.90)$ and $0.60(95 \% \mathrm{CI}=0.13,0.85)$, respectively.

\section{DISCUSSION}

Our results show significant genetic variation between saltcedar families from both Montana and Arizona, the end points of the species' distributional range in the United States. Results also show significant plasticity for all functional traits sampled (morphological and gas exchange). Root biomass investments in cold and hot environments were found to be independent traits and thus can evolve independently (Falconer 1990). Although there were no genetic differences between regions for most traits, we found regional genetic divergence for root biomass investment in cold environments indicating ecotypic differentiation and perhaps local adaptation in seedlings. Overall, phenotypic plasticity, ecotypic differentiation and high genetic variation in saltcedar suggest that the invasive potential of this species is significant.

Consistent with generalized plant responses, gas exchange in saltcedar seedlings decreased significantly in response to decreasing temperatures (Berry and Raison 1981, Korner and Renhardt 1987, Friend and Woodward 1990); however, no genetic variation was detected. In a common garden study, Williams and Black (1993) also found no genetic differences in gas exchange as well as growth among populations of Pennisetum setaceum. They attribute the ability of this species to invade along a broad altitudinal range in Hawaii to phenotypic plasticity. Although our reduced sample size ( $N=82$ plants) for gas exchange traits reduced our ability to detect genetic variation, an analysis of 

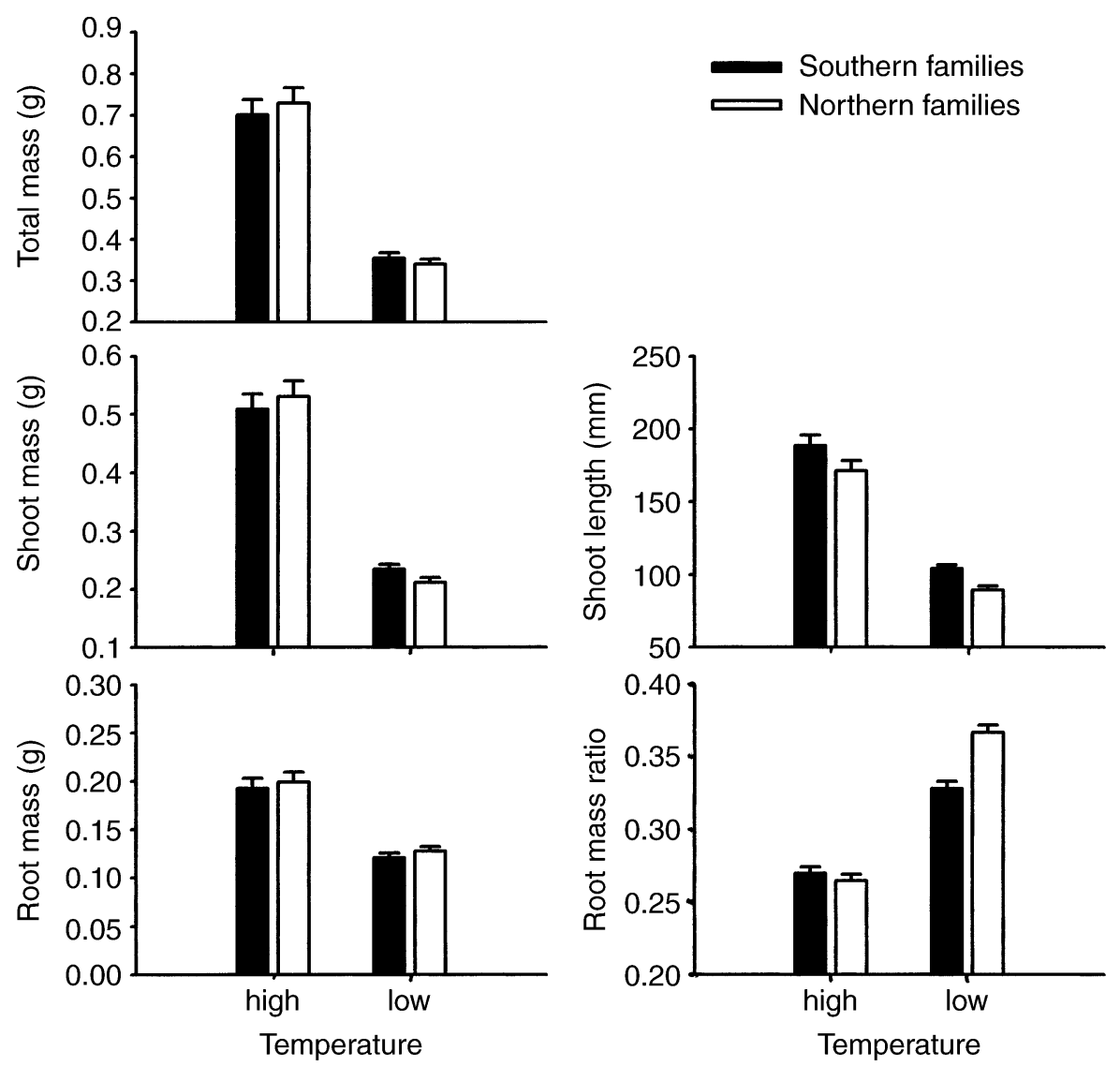

FIG. 2. Biomass allocation and growth in response to temperature for Southern (Arizona) and Northern (Montana) seedlings of Tamarix ramosissima grown in low-temperature $\left(11^{\circ} / 25^{\circ} \mathrm{C}\right)$ and high-temperature $\left(20^{\circ} / 37^{\circ} \mathrm{C}\right)$ environments. Shown are untransformed least-squares means for each region (controlling for harvest time) with vertical bars representing +1 SE. $N$ = 556 seedlings ( 278 for Southern, 278 for Northern) for root mass, total mass, and RMR; 559 (280 for Southern, 279 for Northern) for shoot mass; 530 (265 for Southern, 265 for Northern) for shoot length.

the same sample (blocks 2 and 10) revealed significant genetic variation between regions for shoot length. Thus we have good evidence for plasticity and no evidence for genetic variation in gas exchange traits, although we cannot rule out the possibility of undetected genetic variation.

The amount of genetic variation in non-native populations is affected by genetic drift (the number of introductions, founder population size, founder population diversity, and the breeding system of the invader) as well as selection in the novel habitat (Barrett 1982, Barrett and Richardson 1986, Bazzaz 1986, Novak and Mack 1993). The overall genetic variation in saltcedar's morphological traits was likely imported via multiple introductions from different regions in its native distribution, while geographic structure of the variation may be the result of recombination, intraspecific hybridization, drift, and/or selection since being introduced. This quantitative genetic variation is consistent with preliminary data showing significant variation in haplotypes in populations from the western U.S. (J. Gaskin, personal communication), suggesting a history of multiple introductions. Montana's naturalized populations of saltcedar are thought to have escaped from plantings (for erosion control in irrigation developments) in central and northern Wyoming's Wind/Bighorn systems during the mid to late 1940s (C. Pearce, personal communication). Arizona's older, more invasive populations were spawned from ornamental and erosion control plantings from the late 1800s (Robinson 1965).

In general, cold temperature decreased plant height and increased RMR of saltcedar seedlings. In particular, Northern seedlings were shorter regardless of temperature and invested more in roots, but only when grown at low temperature (i.e., genotype $\times$ environment interaction for root investment). Heritable increases in belowground investment and plant dwarfism are common and have been related to decreased temperature, water, nutrients, and light (Chapin 1980, Ollerenshaw and Baker 1981, Wardlaw et al. 1983, Korner and Renhardt 1987, Friend and Woodward 1990). In cold climates, relative increased investment in roots allows increased belowground storage of reserves while min- 


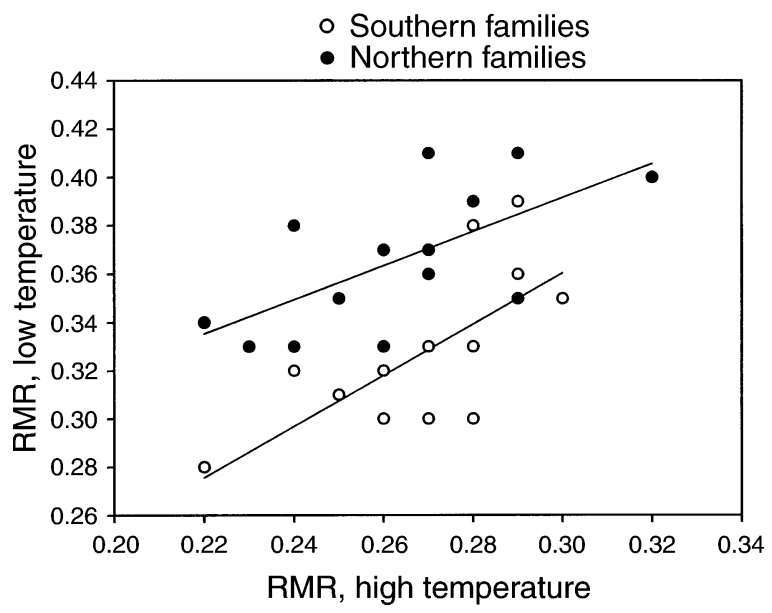

FIG. 3. Scatter plot of least-square family means (controlling for harvest time) for root mass ratio (RMR) in lowtemperature vs. high-temperature chambers. Northern families (solid circles) have significantly higher RMR than Southern families (open circles) in the low-temperature chamber $(y$-axis). In the high-temperature chamber ( $x$-axis) Northern families and Southern families were not significantly different, thus resulting in a significant region $\times$ temperature interaction (Table 2).

imizing heat transfer to the environment (Friend and Woodward 1990).

While seedling traits are clearly important for establishment, we know little about the contribution of recruitment to the intrinsic growth rate of introduced populations. Populations may also have genetically based differences in biomass allocation as adults. We did not analyze heritabilities or further partition genetic variance because we do not know whether our field collected families are full sibs, half sibs, or a mixture. Saltcedar has a self-compatible breeding system (Brotherson and Winkel 1986). The limitation of this experimental design is that we cannot statistically partition additive genetic variance from non-additive genetic variation due to dominance, epistasis, and maternal effects (Hiesey and Milner 1965). However, we removed environmental variance by blocking within families. Significant differences among families within each population suggest that differences between regions are not simply due to maternal effects resulting from large climatic differences between regions.

Controlled growth chamber screening allowed precise measurements during the seedling stage, particularly of relative biomass investment in roots, a fundamental trait during seedling establishment that would be very difficult to measure in the field. Although reciprocal transplants are necessary to test whether differences between regions have fitness consequences, we speculate that greater allocation of biomass to roots in response to cold may be adaptive for the Northern genotypes. If seeds from cold environments (Northern) germinate late in the season, underdeveloped seedlings may undergo high mortality during harsh winters. In- creased relative allocation to roots in cold environments would minimize aboveground tissue losses due to freezing while maximizing resource storage in roots for subsequent growth during the generally shorter growing season. Small adjustments of root biomass can dramatically increase plant performance (Sultan 1992) and strong selection for increased root allocation may quickly affect future generations (Antonovics 1976). From a functional perspective, Northern populations may be experiencing selection for the greater root investment in the cold, or it may be possible that the amount of plasticity itself is responding to selection.

Under hot weather higher investment in aboveground structures would minimize shading by neighbors. In Northern and Southern regions, neighbor competition is particularly important if seeds germinate early in the growing season when native species also germinate (Everitt 1980). Rice et al. (1992) found that increases in shoot biomass in arid steppe populations of Bromus tectorum accelerated development and allowed life-cycle completion during opportune periods when soil moisture was available. Taken together, phenotypic plasticity, ecotypic differentiation, and substantial genetic variation may increase the potential of saltcedar to surpass the lag phase of the invasion process in the peripheries of its invasive range. If northern populations of saltcedar are experiencing selection (either for trait means or for phenotypic plasticity) their invasive potential could increase. The likelihood of adaptive genetic differentiation is increased if populations can persist in an area long enough to experience multiple episodes of natural selection (Barrett 1982). Indeed, saltcedar is persisting in northern, cold regions of the United States (J. Sexton, personal observation).

In light of this and other studies (see Introduction) we caution that levels of standing genetic variation in introduced species may greatly influence their future invasiveness, regardless of their current invasive status. If particular characters such as life history, competitive ability, and resistance to herbivores contribute to invasiveness, then any heritable variation in these characters can lead to evolutionary increases in invasiveness (Ellstrand and Schierenbeck 2000). Finally, the combined influences of founder effects and adaptive evolution following introduction join the list of explanations for the limited success of introducing natural enemies from the native range of invasive species as biological controls (Williamson and Fitter 1996b).

\section{ACKNOWLEDGMENTS}

This research was funded by grants to A. Sala from the NSF-MONTS and the UM Grant Programs. We wish to thank Zack and Shawn Cleveland, Jeremy Moran, Laurie Ashley, and many student volunteers who assisted in propagating and harvesting plants during this experiment. We kindly thank Jon Graham for his statistical expertise and Norman Ellstrand, Martin Lechowicz, Monique Kolster, and two anonymous reviewers for their helpful comments. 


\section{Literature Cited}

Antonovics, J. 1976. The nature of limits to natural selection. Annals of the Missouri Botanical Garden 63:224-247.

Baker, H. G. 1974. The evolution of weeds. Annual Review of Ecology and Systematics 5:1-24.

Baker, H. G. 1986. Patterns of plant invasion in North America. Pages 44-57 in H. A. Mooney and J. A. Drake, editors. Ecology of biological invasions of North America and Hawaii. Springer-Verlag, New York, New York, USA.

Barrett, S. C. H. 1982. Genetic variation in weeds. Pages 73-98 in R. Charudattan and H. Walker, editors. Biological control of weeds with plant pathogens. John Wiley, New York, New York, USA.

Barrett, S. C. H., and H. J. Richardson. 1986. Genetic attributes of invading species. Pages 21-33 in R. H. Groves and J. J. Rurdon, editors. Ecology of biological invasions. Academy of Science, Canberra, Australia.

Baum, B. R. 1978. The genus Tamarix. Israel Academy of Sciences and Humanities, Jerusalem, Israel.

Bazzaz, F. A. 1986. Life history of colonizing plants: some demographic, genetic, and physiological features. Pages 96-110 in R. Charudattan and H. Walker, editors. Biological control of weeds with plant pathogens. John Wiley, New York, New York, USA.

Bell, G., and M. J. Lechowicz. 1994. Spatial heterogeneity at small scales and how plants respond to it. Pages 391414 in M. M. Caldwell and R. W. Pearcy, editors. Exploitation of environmental heterogeneity by plants: ecophysiological processes above and below ground. Academic Press, San Diego, California, USA.

Berry, J., and O. Bjorkman. 1980. Photosynthetic response and adaptation to temperature in higher plants. Annual Review of Plant Physiology 31:491-543.

Berry, J., and J. K. Raison. 1981. Responses of macrophytes to temperature. Pages 278-338 in O. L. Lange, P. S. Nobel, C. B. Osmond, and H. Ziegler, editors. Encyclopedia of plant physiology. Volume 12A. Springer-Verlag, Berlin, Germany.

Brock, J. H. 1994. Tamarix spp. (salt cedar), an invasive exotic woody plant in arid and semi-arid riparian habitats of Western USA. Pages 27-44 in L. C. de Waal, L. E. Child, P. M. Wade, and J. H. Brock, editors. Ecology and management of invasive riverside plants. Wiley and Sons.

Brotherson, J. D., and V. Winkel. 1986. Habitat relationships of saltcedar (Tamarix ramosissima) in central Utah. Great Basin Naturalist 46:535-541.

Busch, D. E., and S. D. Smith. 1995. Mechanisms associated with decline of woody species in riparian ecosystems of the southwestern U.S. Ecological Monographs 65:347-370.

Chapin, F. S., III. 1980. The mineral nutrition of wild plants. Annual Review of Ecology and Systematics 11:233-260.

Clausen, J., D. D. Keck, and W. M. Hiesey. 1948. Experimental studies on the nature of species. III. environmental responses of climatic races of Achillea. Carnegie Institute of Washington Publications 581:1-125.

Cleverly, J. R., S. D. Smith, A. Sala, and D. A. Devitt. 1997. Invasive capacity of Tamarix ramosissima in a Mojave Desert floodplain: the role of drought. Oecologia 111:12-18.

Ellstrand, N. C., and K. A. Schierenbeck. 2000. Hybridization as a stimulus for the evolution of invasiveness in plants. Proceedings of the National Academy of Sciences 97:7043-7050.

Everitt, B. L. 1980. Ecology of saltcedar: a plea for research. Environmental Geology 3:77-84.

Falconer, D. S. 1990. Selection in different environments: effects on environmental sensitivity (reaction norm) and on mean performance. Genetical Research, Cambridge 56:5770.

Freund, R. J., R. C. Littell, and P. C. Spector. 1991. SAS system for linear models. SAS Institute, Inc., Cary, North Carolina.

Friend, A. D., and F. L. Woodward. 1990. Evolutionary and ecophysiological responses of mountain plants to the growing season environment. Advances in Ecological Research 20:59-124.

Fry, J. D. 1992. The mixed-model analysis of variance applied to quantitative genetics: biological meaning of the parameters. Evolution 46:540-550.

Garwood, A. N. 1996. Weather America: latest detailed climatological data for over 4,000 places-with rankings. Toucan Valley Publications, Milpitas, California, USA.

Gingerich, P. D. 1983. Rates of evolution: effects of time and temporal scaling. Science 222:159-161.

Goodwin, B. J., A. J. McAllister, and L. Fahrig. 1999. Predicting invasiveness of plant species based on biological information. Conservation Biology 13:422-426.

Haase, E. F. 1972. Survey of floodplain vegetation along the lower Gila River in southwestern Arizona. Journal of the Arizona Academy of Science 7:75-81.

Hansen, P. L., R. D. Pfister, K. Boggs, B. J. Cook, J. Joy, and D. K. Hinckley. 1995. Classification and management on Montana's riparian and wetland sites. Montana Forest and Conservation Experiment Station, School of Forestry, University of Montana, Miscellaneous Publication no. 54.

Hiesey, W. M., and H. W. Milner. 1965. Physiology of ecological races and species. Annual Review of Plant Physiology 16:203-216.

Huey, R. B., G. W. Gilchrist, M. L. Carlson, D. Berrigan, and L. Serra. 2000. Rapid evolution of a geographic cline in size in an introduced fly. Science 287:308-309.

Hume, L., and P. B. Cavers. 1982. Geographic variation in a widespread perennial weed, Rumex crispus. The relative amounts of genetic and environmentally induced variation among populations. Canadian Journal of Botany 60:19281937.

Jain, S. K., and A. D. Bradshaw. 1966. Evolutionary divergence among adjacent plant populations. I. evidence and its theoretical analysis. Heredity 21:407-441.

Jain, S. K., and P. S. Martins. 1979. Ecological genetics of the colonizing ability of rose clover (Trifolium hirtum ALL.). American Journal of Botany 66:361-366.

Korner, C., and U. Renhardt. 1987. Dry matter partitioning and root length/leaf area ratios in herbaceous perennial plants with diverse altitudinal distribution. Oecologia 74: 411-418.

Lacey, E. P. 1988. Latitudinal variation in reproductive timing of a short-lived monocarp, Daucus carota (Apiaceae). Ecology 69:220-232.

Lesica, P., and S. Miles. 2001. Tamarisk growth at the northern margin of its naturalized range in Montana, USA. Wetlands 21:240-246.

Linhart, Y. B., and M. C. Grant. 1996. Evolutionary significance of local genetic differentiation in plants. Annual Review of Ecology and Systematics 27:237-277.

Mack, R. N., D. Simberloff, W. M. Lonsdale, H. Evans, M. Clout, and F. A. Bazzaz. 2000. Biotic invasions: causes, epidemiology, global consequences, and control. Ecological Applications 10:689-710.

Martin, M. M., and J. Harding. 1980. Evidence for the evolution of competition between two species of annual plants. Evolution 35:975-987.

McGraw, J. B. 1987. Experimental ecology of Dryas octopetela ecotypes IV. fitness responses to reciprocal transplanting in ecotypes with differing plasticity. Oecologia 73: 465-468.

Minckley, W. L., and D. E. Brown. 1994. Wetlands. Pages 222-287 in D. E. Brown, editor. Biotic communities: southwestern United States and northwestern Mexico. University of Utah Press, Salt Lake City, Utah. 
Novak, S. J., and R. N. Mack. 1993. Genetic variation in Bromus tectorum (Poaceae): comparison between native and introduced populations. Heredity 71:167-176.

Ollerenshaw, J. H., and R. H. Baker. 1981. Low temperature growth in a controlled environment of Trifolium repens plants from northern latitudes. Journal of Applied Ecology 18:229-239.

Potvin, C., and S. Tardif. 1988. Sources of variability and experimental design in growth chambers. Functional Ecology 2:122-130.

Rejmánek, M., and D. M. Richardson. 1996. What attributes make some plant species more invasive? Ecology 77:16651671.

Rice, K. J., R. A. Black, G. Radamaker, and R. D. Evans. 1992. Photosynthesis, growth, and biomass allocation in habitat ecotypes of cheatgrass (Bromus tectorum). Functional Ecology 6:32-40.

Rice, K. J., and R. N. Mack. 1991. Ecological genetics of Bromus tectorum. III. the demography of reciprocally sown populations. Oecologia 88:91-101.

Robinson, T. W. 1965. Introduction, spread and areal extent of saltcedar (Tamarix) in the western states. Geological Survey Professional Paper 491-A.

Sala, A., S. D. Smith, and D. A. Devitt. 1996. Water use by Tamarix ramosissima and associated phreatophytes in a Mojave Desert floodplain. Ecological Applications 6:888898.

Schlichting, C. D. 1986. The evolution of phenotypic plasticity in plants. Annual Review of Ecology and Systematics 17:667-693.

Smith, S. D., D. A. Devitt, A. Sala, J. R. Cleverly, and D. E. Busch. 1998. Water relations of riparian plants from warm desert regions. Wetlands 18:687-696.

Sokal, R. R., and F. J. Rolf. 1995. Biometry. W. H. Freeman, San Francisco, California, USA.
Stearns, S. C. 1989. The evolutionary significance of phenotypic plasticity. BioScience 39:436-445.

Sultan, S. E. 1987. Evolutionary implications of phenotypic plasticity in plants. Evolutionary Biology 21:127-178.

Sultan, S. E. 1992. Phenotypic plasticity and the neo-Darwinian legacy. Evolutionary Trends in Plants 6:61-71.

Via, S. 1994. The evolution of phenotypic plasticity: what do we really know? Pages 35-85 in L. Real, editor. Ecological genetics. Princeton University Press, Princeton, New Jersey, USA.

Via, S., R. Gomulkiewicz, G. de Jong, S. Scheiner, C. D. Schlichting, and P. H. van Tienderen. 1995. Adaptive phenotypic plasticity: consensus and controversy. Trends in Ecology and Evolution 5:212-217.

Wardlaw, I. F., J. E. Begg, D. Bagnall, and R. L. Dunstone. 1983. Jojoba temperature adaptation in growth and leaf function. Australian Journal of Plant Physiology 10:299312 .

Warren, D. K., and R. M. Turner. 1975. Saltcedar (Tamarix chinensis) seed production seedling establishment and response to inundation. Journal of Arizona Academy of Science 10:135-144.

Williams, D. G., and R. A. Black. 1993. Phenotypic variation in contrasting temperature environments: growth and photosynthesis in Pennisetum setaceum from different altitudes on Hawaii. Functional Ecology 7:623-633.

Williams, D. G., R. N. Mack, and R. A. Black. 1995. Ecophysiology of introduced Pennisetum setaceum on Hawaii: the role of phenotypic plasticity. Ecology 76:1569-1580.

Williamson, M. H., and A. Fitter. 1996a. The characters of successful invaders. Biological Conservation 78:163-170.

Williamson, M., and A. Fitter. 1996b. The varying success of invaders. Ecology 77:1661-1666.

Woodward, F. I. 1986. Ecophysiological studies on the shrub Vaccinium myrialis L. taken from a wide altitudinal range. Oecologia 70:580-586. 